DOI: $\underline{\text { http://dx.doi.org/10.21123/bsj.2016.13.1.0044 }}$

\title{
The Protective Effect of Radish (Raphanus sativus) Seeds Against the Oxidative Stress Induced by Sodium Nitrite in Male Rabbits (Oryctolagus cuniculus)
}

\author{
Lena A. Abed-Alazeez \\ Alia H. Ali \\ Mukhtar K. Haba
}

Department of Biology, College of Science for Women, University of Baghdad

Received 15, December, 2014

Accepted 15, February, 2015

(i) $\Theta$

EY No This work is licensed under a Creative Commons Attribution-NonCommercial-

$\underline{\text { NoDerivatives 4.0 International Licens }}$

\begin{abstract}
:
The aim of this study is to investigate the protective effect of Radish (Raphanus sativus) seed alcoholic extract $70 \%$ against oxidative stress induced by sodium nitrite $\mathrm{NaNO}_{2}$ Twenty five adult male rabbits were devided into five groups of (five rabbits in each group) and treated daily for 30 days. Group T1: intubated orally $20 \mathrm{mg} / \mathrm{kg}$ $\mathrm{NaNO}_{2}$, Group T2: intubated orally $20 \mathrm{mg} / \mathrm{kg} \mathrm{NaNO}{ }_{2}+50 \mathrm{mg} / \mathrm{kg}$ of alcoholic extract from Raphanus sativus seeds, Group T3: intubated orally $20 \mathrm{mg} / \mathrm{kg} \mathrm{NaNO} \mathrm{Na}_{2}+100$ $\mathrm{mg} / \mathrm{kg}$ of alcoholic extract from Raphanus sativus seeds, Group T4: intubated orally $20 \mathrm{mg} / \mathrm{kg} \mathrm{NaNO} \mathrm{Na}_{2}+200 \mathrm{mg} / \mathrm{kg}$ of alcoholic extract from Raphanus sativus seed as well as Group C: control intubated orally distilled water. In comparison with normal rabbits there were significantly increase in the level of Methemoglobin ( $\mathrm{MetHb} \%)$, lipid peroxidation indicator malondialdehyde (MDA), and significantly decrease in the level of glutathione (GSH) in the rabbits intubated $\mathrm{NaNO}_{2}$. In rabbits intubated $\mathrm{NaNO}_{2}+50,100,200 \mathrm{mg} / \mathrm{kg}$ of alcoholic extract it was found there were significant decreased in the level of MetHb\%, MDA, and increase in the level of GSH. In conclusion according to results obtained from this study approved that alcoholic extract of Raphanus sativus seeds in dose $(50,100,200 \mathrm{mg} / \mathrm{kg})$ have protective effect against oxidative stress induced by sodium nitrite in male rabbits.
\end{abstract}

Key words: Radish seed, Sodium nitrite, Methemoglobin (MetHb), malondialdehyde (MDA), glutathione (GSH).

\section{Introduction:}

Food Additives are used for maintaining the high quality of foods. Food preservatives are the additives that are used to inhibit the growth of bacteria, molds and yeasts in the food. Sodium nitrite, an inorganic salt is used as a preservative and a color fixative in meats and fish it stabilizes the color of preserved fish and meats and also it inhibits the growth of Clostridium botulinum[1].

Sodium nitrite with both healthful and harmful effects, acts as vasodilator, Bronchial dilator Intestinal relaxant [2], Antidote for cyanide poisoning [3] resp. The toxic effects of nitrites in various mammalian species involved hepatotoxicity, nephrotoxicity, deterioration of reproductive function, endocrine disturbance, growth retardation, dysregulation of inflammatory responses and cause 
tissue injury[4]. Sodium nitrite exerts its effect by increase production of free radicals that cause imbalance pro-oxidant / anti-oxidant system . The main biological effects of nitrite in human include the oxidation of normal haemoglobin $(\mathrm{Hb})$ to methaemoglobin (metHb). The latter is unable to transport oxygen to the tissues. Increase the level of metHb cause cyanosis and, at higher concentrations, asphyxia. Nitrite methemoglobinemia is a process that responsible for free radical generation. Free radicals are reactive molecules these have one or more unpaired electrons and are naturally produced in human body by natural biological processes or may be resulting from an outside source (such as tobacco smoke, toxins, or pollutants). These free radicals are toxic compounds that can attack and damage biomolecules, including proteins, nuclei acids and lipids. These damages cause different diseases including atherosclerosis, arthritis, neurodegenerative disorders and cancer etc [5]. It has been reported that Nitrite has been enhance lipid peroxidation (LPO) and cause change in antioxidant enzyme activity. Previous studies suggest that intracellular reactive oxygen species (ROS) production is a possible mechanism underlying nitrite toxicity. These reactive oxygen species (ROS) induce lipid peroxidation (LPO), a chain process which affects unsaturated fatty acids mainly localized in cell membranes leading to generation of malondialdehyde. These damages can be neutralized with antioxidant systems such as glutathione, glutathione reductase, etc. and nutritional antioxidants from diet such as Ascorbic acid (vitamin C), Tocopherols and tocotrienols (vitamin E) carotenoids etc. Glutathione is one of the major studied antioxidants. it is present in all the cells. GSH act as antioxidant and detoxification of ROS. If the natural antioxidants are unable to scavenger the ROS, when free radicals cause damage to the molecules, a condition known as oxidative stress occurs where in cellular function can be affected and cells may be damaged[6]. Risks associated with food preservatives urged for study the protective effect of Radish seed against the hazardous effect of sodium nitrite. Radish has been used as medicinal foods for several disease, involving liver dysfunction and poor Digestion[7]. There are some studies which showed that the radishes or radish extracts have biological activities including antioxidant, Antimutagenic, and antiproliferative effects [8]. Previous study Explained that R. sativus extract have a protective effect against sodium nitrite that lead to elevated blood $\mathrm{MetHb} \%$ and MDA and lowering GSH level , white R.sativus seed extract revealed that this extract have antioxidant effect by increasing GSH level and lowering MetHb and MDA level [9].

\section{Materials and Methods:}

\section{Animals and experimental design}

In this study, 25 adult male rabbits were kept in conditioned room (22$25^{\circ} \mathrm{C}$ ) with providing proper ventilation. Rabbits were left for two weeks for adaptation with the experimental conditions. Animals treated daily for four weeks. They were randomly divided into five groups, (5 rabbits/group). Group C (control): administered distilled water orally, Group T1: Animals in this group were administered $20 \mathrm{mg} / \mathrm{kg}$ b.w of sodium nitrite orally by gavage needle, Group T2: Animals in this group were administered $20 \mathrm{mg} / \mathrm{kg}$ b.w of sodium nitrite plus $50 \mathrm{mg} / \mathrm{kg}$ b.w of ethanol extract from (Raphinus sativus) orally by gavage needle,. 
Group T3: Animals in this group were administered $20 \mathrm{mg} / \mathrm{kg}$ b.w of sodium nitrite plus $100 \mathrm{mg} / \mathrm{kg}$ b.w ethanol extract from (Raphinus sativus) orally by gavage needle. Group T4: Animals in this group were administered 20 $\mathrm{mg} / \mathrm{kg} \mathrm{b.w}$ of sodium nitrite plus 200 $\mathrm{mg} / \mathrm{kg}$ b.w ethanol extract from (Raphinus sativus) orally by gavage needle. Fasting Blood samples were collected from animals by cardiac puncture technique and MetHb , MDA, GSH parameters were then measured.

\section{Plant materials}

The plant materials (seeds) were obtained from commercial sources from Baghdad and then deposited to be identified and authenticated at the National Herbarium of Iraq Botany directorate in Abu-Ghraib. The plant materials were extracted according to [10].

Phytochemical analysis: There were

two tests for detection of one active compound.

Detection of Alkaloids by Mayer's test:- Appeared of white or creamy precipitate indicate the presence of alkaloids. Detection of Alkaloids by wagner's test:- A reddish or brown precipitate appeared indicate the presence of alkaloids.

Detection of Saponins by Foam test:-1 cm layer of faom appeared indicate the presence of saponins. Detection of Saponins by Mercuric chloride test:- Appearance of white precipitate indicate the presence of saponins.

Detection of Tannins by Ferric chloride test:-A dark green color appeared indicate the presence of Tannins. Detection of Tannins by Lead acetates test:- Bulky red precipitate indicate the presence of Tannins.

Detection of Terpenoids by Chloroform-sulphuric acid test :-A reddish brown colour indicate the presence of Terpenoids. Detection of Terpenoids by Anace-aldihyde test:- A brown precipitate indicate the presence of Terpenoids.

Detection of Flavonoids by Magnecium test :- Appearance of pink to crimson colour indicate the the presence of flavonoids. Detection of Flavonoids by Sulphuric acid test:- A greenish yellow precipitate appeared indicate the presence of flavonoids [11].

\section{Determination of Metheamoglobin} (MetHb)

MetHb level was determined according to the method of [12]. Add $0.1 \mathrm{ml}$ of blood test tube containing 3.9 $\mathrm{ml}$ of distilled water and mixed well. Add $4 \mathrm{ml}$ of phosphate buffer saline PBS and mixed well. Add $(1.5 \mathrm{ml})$ of PBS and $(1.5 \mathrm{ml})$ of distilled water to blank cuvet... this is $\mathrm{C} 1$. Then $3 \mathrm{ml}$ of hemolysate blood was added to test tube $\mathrm{C} 2, \mathrm{C} 3$. Then, add $(0.1 \mathrm{ml})$ of $\mathrm{K}_{3} \mathrm{Fe}(\mathrm{CN})_{6}$ to one test tube and mixed three times and left for two minutes. Measuring the absorbance at wavelength $630 \mathrm{~nm}$ of each C2, C3 with use $\mathrm{C} 1$ as a blank. The result recorded as A2a, A3a. Then add $(0.1 \mathrm{ml})$ of $\mathrm{KCN}$ to test tube $\mathrm{C} 2$ and $\mathrm{C} 3$. Mixed three times and left for 5 minutes, the absorbance measured again at the same wave length with use $\mathrm{C} 1$ as blank, the result recorded as $\mathrm{A} 2 \mathrm{~b}$ , A3b.

Metheamoglobin (percent of total pigment $)=\{(\mathrm{A} 2 \mathrm{a}-\mathrm{A} 2 \mathrm{~b}) /(\mathrm{A} 3 \mathrm{a}-$ A3b) $\} \times 100$

\section{Determination of \\ Malondialdehyde (MDA)}

Determination of MDA according to the method of [13]. One hundred fifty $\mu \mathrm{L}$ of serum sample was poured in a test tube and $1 \mathrm{ml}$ of $17.5 \%$ TCA was added, then one milliliter of $0.6 \%$ TBA was added. Tubes were mixed well by vortex, incubated in boiling water bath for 15 minutes, and then allowed to cool, then one milliliter of $70 \%$ TCA was added, The mixture was left to stand at room temperature for 20 
minutes then the tubes were centrifuged at $2000 \mathrm{Xg}$ for 15 minutes, and the supernatant was taken out for measuring spectrophotometrically (at $532 \mathrm{~nm}$ ).

Malondialdehyde (MDA) concentration $=($ Absorbance $/ \mathrm{L} \times \varepsilon) \times \mathrm{D}$

L: Light bath $(\mathrm{cm}), \quad \varepsilon$ : Extinction coefficient $1.56 \times 10^{5} \mathrm{M}^{-1} \mathrm{Cm}^{-1} \mathrm{D}$ : Dilution factor $=($ volume used in Ref. $(\mathrm{ml}) / 0.15)=(1+1+1+0.15) / 0.15=$ 21

\section{Determination of Glutathione (GSH)}

Determination of Glutathione (GSH) according to the method of [14]. Duplicates of each standard and sample test tubes were prepared. Solutions were mixed as in the following:

\begin{tabular}{|c|c|c|c|}
\hline Reagents & $\begin{array}{c}\text { Sample } \\
(\mu \mathrm{L})\end{array}$ & $\begin{array}{c}\text { Reagent } \\
\text { blank }(\mu \mathrm{L})\end{array}$ & $\begin{array}{c}\text { Standard } \\
(\mu \mathrm{L})\end{array}$ \\
\hline Serum & 100 & - & - \\
\hline Standard & - & - & 100 \\
\hline DW & 800 & 900 & 800 \\
\hline TCA & 100 & 100 & 100 \\
\hline
\end{tabular}

Tubes were mixed in a vortex mixer intermittently for $10-15 \mathrm{~min}$, and centrifuged for $15 \mathrm{~min}$ at $3000 \mathrm{xg}$, then pipette into test tubes.

\begin{tabular}{|c|c|c|c|}
\hline Reagents & $\begin{array}{c}\text { Sample } \\
(\mu \mathrm{L})\end{array}$ & $\begin{array}{c}\text { Reagent } \\
\text { blank }(\mu \mathrm{L})\end{array}$ & $\begin{array}{c}\text { Standard } \\
(\mu \mathrm{L})\end{array}$ \\
\hline Supernatant & 400 & 400 & 400 \\
\hline Tris-EDTA & 800 & 800 & 800 \\
\hline $\begin{array}{c}\text { DTNB } \\
\text { reagent }\end{array}$ & 20 & 20 & 20 \\
\hline
\end{tabular}

Tubes were mixed in a vortex mixer, the spectrophotometer was adjusted with reagent blank to read zero absorbance (A) at $412 \mathrm{~nm}$ and the absorbance of standards and sample was read with in $3 \mathrm{~min}$ of the addition of the DTNB reagent, The concentration of serum GSH is obtained from the calibration curve in $\mu \mathrm{M}$ :-

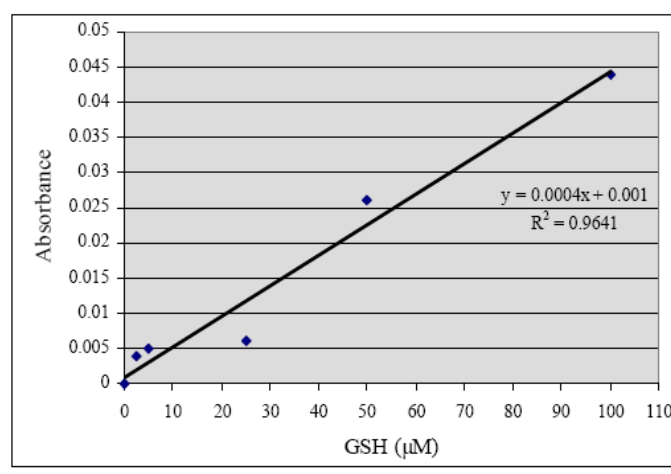

Fig. (1): calibration curve for serum glutathione (GSH) concentration $(\mathrm{mmol} / \mathrm{L})$

\section{Results:}

The results of phytochemical analysis in table $\{1\}$ explained that Raphanus sativus seed contains some of active ingredients that include:

Table (1): Phytochemical analysis of Raphanus sativus seed

\begin{tabular}{|c|c|}
\hline $\begin{array}{c}\text { Active } \\
\text { ingredients }\end{array}$ & Reagents or Tests \\
\hline Alkaloids & $\begin{array}{c}\text { Mayer's Reagent (+), } \\
\text { Wagner's reagent (+) }\end{array}$ \\
\hline saponins & $\begin{array}{c}\text { foam test }(+), \text { Mercuric } \\
\text { chloride test }(+)\end{array}$ \\
\hline Tannins & $\begin{array}{c}\text { Ferric chloride test }(+), \\
\text { Lead acetates test (+) }\end{array}$ \\
\hline flavonoids & $\begin{array}{c}\text { Magnecium test }(+), \\
\text { Sulphuric acid test (+) }\end{array}$ \\
\hline Terpenoids & $\begin{array}{c}\text { Chloroform, } \mathrm{H}_{2} \mathrm{SO}_{4}(+), \\
\text { Anace-aldihyde reagent (+) }\end{array}$ \\
\hline
\end{tabular}

The results of current study explained methemoglobin (MetHb\%) level in table $\{2\}$ that there was a significant increase $(\mathrm{P} \leq 0.05)$ in MetHb\% level in animals treated with sodium nitrite compared with control(C), and there was a significant decrease in animals treated with sodium nitrite and Raphanus sativus seed extract $(50,100,200 \mathrm{mg} / \mathrm{kg})$ compared animal group treated with sodium nitrite and normalize the level of MetHb\% in $\mathrm{T}_{2}, \mathrm{~T}_{3}, \mathrm{~T}_{4}$ as compared with control. 
Table (2): The Effect of 70\% Raphanus sativus seed extract in Methemoglobin (MetHb\%) in control and sodium nitrite treated rabbits

\begin{tabular}{|c|c|c|c|c|c|c|}
\hline \multirow{2}{*}{ Stage } & \multicolumn{5}{|c|}{ Treatment } & \multirow{2}{*}{ LSD value } \\
\cline { 2 - 6 } & Cont. & T1 & T2 & T3 & T4 & \multirow{2}{*}{6.83 NS } \\
\hline Pre & $12.22 \pm 0.35$ & $11.5 \pm 0.39^{\mathrm{a}}$ & $\begin{array}{c}11.66 \pm 0.42 \\
\mathrm{a}^{\mathrm{a}}\end{array}$ & $11.86 \pm 0.55^{\mathrm{a}}$ & $12.18 \pm 0.38^{\mathrm{a}}$ & \\
\hline Post & $11.74 \pm 0.41^{\mathrm{b}}$ & $40.92 \pm 1.8^{\mathrm{a}}$ & $8.17 \pm 0.26^{\mathrm{b}}$ & $10.76 \pm 0.63^{\mathrm{b}}$ & $12.40 \pm 0.41^{\mathrm{b}}$ & $13.59 *$ \\
\hline LSD value & $5.77 \mathrm{NS}$ & $12.68 *$ & $6.84 \mathrm{NS}$ & $5.72 \mathrm{NS}$ & $5.09 \mathrm{NS}$ & --- \\
\hline \multicolumn{7}{|c}{$*(\mathrm{P} \leq 0.05)$, NS: Non-significant. } \\
\hline
\end{tabular}

Values expressed as mean $\pm \mathrm{SE} \mathrm{n}=5$ each group; $\mathrm{C}$ : control group; $\mathrm{T}_{1}$ : animals received $20 \mathrm{mg} / \mathrm{kg} \quad$ B.W sodium nitrite orally; $\mathrm{T}_{2}$ : animals received $20 \mathrm{mg} / \mathrm{kg}$ B.W sodium nitrite $+50 \mathrm{mg} / \mathrm{kg}$ B.W Raphanus sativus seed extract; $\mathrm{T}_{3}$ : animals received 20 $\mathrm{mg} / \mathrm{kg}$ B.W sodium nitrite +100 $\mathrm{mg} / \mathrm{kg}$ B.W Raphanus sativus seed extract; $\mathrm{T}_{4}$ : animals received $20 \mathrm{mg} / \mathrm{kg}$ B.W sodium nitrite $+200 \mathrm{mg} / \mathrm{kg}$ B.W Raphanus sativus seed extract. Small letters denote differences between groups, $\mathrm{P} \leq 0.05 \mathrm{Vs}$ control.

The results of table $\{3\}$ show that there was a significant increase
$(\mathrm{P} \leq 0.05)$ in serum level of malondialdehyde (MDA) in animal treated with sodium nitrite compared with control(C), and non-significant increase in animals treated with sodium nitrite and Raphanus sativus seed extract $(50,100,200 \quad \mathrm{mg} / \mathrm{kg})$ compared with control, but there was a significant decrease in the level of MDA in animals treated with sodium nitrite and Raphanus sativus seed extract $(50,100,200 \mathrm{mg} / \mathrm{kg})$ compared with animal group treated with sodium nitrite.

Table (3): The Effect of 70\% Raphanus sativus seed extract on serum malondialdehyde (MDA) concentration $(\mathrm{mmol} / \mathrm{L})$ in adult male rabbits

\begin{tabular}{|c|c|c|c|c|c|c|}
\hline \multirow{2}{*}{ Parameter } & \multicolumn{5}{|c|}{ Treatment } & \multirow{2}{*}{ LSD value } \\
\hline & Cont. & T1 & $\mathrm{T} 2$ & T3 & $\mathrm{T} 4$ & \\
\hline MDA & $0.133 \pm 0.005^{b}$ & $0.516 \pm 0.029^{\mathrm{a}}$ & $0.264 \pm 0.007^{b}$ & $0.228 \pm 0.003^{b}$ & $0.158 \pm 0.003^{b}$ & $0.218 *$ \\
\hline \multicolumn{7}{|c|}{$*(\mathrm{P} \leq 0.05)$} \\
\hline
\end{tabular}

Values expressed as mean $\pm \mathrm{SE} n=5$ each group.

The results of table $\{4\}$ show that there was a significant decrease in serum level of glutathione (GSH) in animal treated with sodium nitrite compared with control, and there was a significant decrease in animals treated with sodium nitrite and Raphanus sativus $(50,100,200 \mathrm{mg} / \mathrm{kg})$ as compared with control. also there was non significant increase in serum level of GSH in animals treated with sodium nitrite and Raphanus sativus $(50,100 \mathrm{mg} / \mathrm{kg})$ compared sodium nitrite animals group, and there was a significant increase in serum level of GSH in animals treated with sodium nitrite and Raphanus sativus (200 $\mathrm{mg} / \mathrm{kg}$ ) compared with animal group treated with sodium nitrite.

Table (4): The Effect of 70\% Raphanus sativus seed extract on serum glutathione (GSH) concentration ( $\mathrm{mmol} / \mathrm{L})$ in adult male rabbits

\begin{tabular}{|c|c|c|c|c|c|c|}
\hline \multirow[b]{2}{*}{ Parameter } & \multicolumn{5}{|c|}{ Treatment } & \multirow[b]{2}{*}{ LSD value } \\
\hline & Cont. & T1 & $\mathrm{T} 2$ & T3 & T4 & \\
\hline GSH & $4.446 \pm 0.26^{\mathrm{a}}$ & $2.234 \pm 0.13^{\mathrm{c}}$ & $2.756 \pm 0.17^{\mathrm{bc}}$ & $2.856 \pm 0.09^{\mathrm{bc}}$ & $3.51 \pm 0.14^{\mathrm{b}}$ & $0.872 *$ \\
\hline
\end{tabular}

Values expressed as mean \pm SE $n=5$ each group. 


\section{Discussion:}

The results of the present study pointed to significant change in MetHb level in group treated with sodium nitrite. This change manifested by an increase in MetHb level in agreement with [15]. The main toxic effect of sodium nitrite, It acts as pro-oxidant induces a primary extensive methemoglobin formation as a result of production of several free radical species such as hydroxyl, superoxide anion, peroxynitrite and nitrogen oxide radicals which are implicated in promoting oxidation of $\mathrm{Hb}$ by nitrite. Nitrite reacts with oxygenated $\mathrm{Hb}$ to form metHb and nitrate $\left(\mathrm{NO}_{3}{ }^{-}\right)$, and it reacts with deoxygenated $\mathrm{Hb}$ to form metHb and nitric oxide (NO) leading to methemoglobinemia . Nitrite is readily absorbed from the digestive tract and diffuses into the red blood cells where it oxidizes the ferrous ion $\left(\mathrm{Fe}^{+2}\right)$ of the oxyhemoglobin (oxy $\mathrm{Hb}$ ) molecules to the ferric state $\left(\mathrm{Fe}^{+3}\right)$ forming met $\mathrm{Hb}$. Elevation of MetHb level lead to reduce of oxygen transport, And when MetHb levels increase can be life threatening [16]. The results of current study showed that significant decrease glutathione (GSH) level and Elevation of malondialdehyde (MDA) level indicate for lipid peroxidation in group treated with sodium nitrite, These results agreed with those reported by [17], [18], [19]. The high MDA level in serum may reflect the oxidative stress exerted different tissues as it has been reported that oxidant/antioxidant status may reflect the extracellular response to the external agents or the tissue status. These results indicated elevated lipid peroxide, Malondialdehyde. The elevated amounts of MDA may be due to generation of reactive oxygen species (ROS) and also attributed to the depletion of liver GSH resulting in tissue degeneration and elevated lipid peroxidation products in target organs. $\mathrm{NaNO}_{2}$ inhibited glutathione activity in the plasma may be attributed to the observed induction of lipid perpxidation (LPO) and may be explained according to their function as a free radical scavenger, which suppress the formation of the reactive oxygen species (ROS) and/or oppose their action [20]. The decreased GSH content in the present study may be attributed to the increased LPO rather than reduced synthesis [21]. Glutathione (GSH) is a major nonenzymatic antioxidant molecule that is involved in the second line of defense against free radical damage in the body. GSH donates an electron in the reduction of peroxides catalyzed by Glutathione peroxidase (GSHpx) as a component of the enzyme system containing GSH oxidase and reductase. Some studies observed a decreased level of GSH, this is due to the most hepatic reduced glutathione (GSH) is converted to its oxidized form Glutathione disulfide (GSSG) by the enzyme glutathione reductase that protect the cells from damage caused by free radicals. Previous studies suggested that the decrease in GSH level may be due to the consumption of antioxidants and the increased production of ROS due to the toxic action of nitrosamine and free radicals generated by sodium nitrite [22].

According to The results of the current study which showed that there was a significant decrease in level of MetHb and MDA in animals treated with sodium nitrite and Raphanus sativus seed extract $(50,100,200$ $\mathrm{mg} / \mathrm{kg}$ ) compared animal group treated with sodium nitrite only, and there is significant increase in serum level of GSH in animals treated with sodium nitrite and Raphanus sativus (200 $\mathrm{mg} / \mathrm{kg}$ ) compared with animal group treated with sodium nitrite. These 
results agreed with [23] explained that the radish fed group decrease free radicals production. This was indicated by the lowest the level of malondialdehyde and the reactive nitrogen species, specifically the powerful oxidant molecule peroxynitrite (ONOO). Radish seeds were found to contain alkaloid such as flavonoids, saponins, coumarins and anthocyanins .The anthocyanins are important dietary antioxidants that have many physiological functions. They protect living cells from harmful effect of oxidative stress resulting in the prevention of diseases .Oil of Raphani Semen was revealed to have significant antioxidative activity in the ferric reducing antioxidant power assay[24]. R. sativus is one of the major sources of dietary flavonoids which are powerful antioxidants against free radicals and are described as free-radical scavengers[25].

\section{References}

[1]Grosse, Y.; Baan, R.; Straif, K.; Secretan, B. and El-Ghissassi, F. 2006. Cogliano V WHO International Agency for Research on Cancer Monograph Working Group Carcinogenicity of nitrate, nitrite, and cyanobacterial peptide toxins. Lancet Oncol., 7: 628-629.

[2]Hunter, C. J. ; Dejam, A. B.; Blood, A. B.; Shields, H. ; Kim-Shapiro, D. B.; Machado, R. F.; Tarekegn S.; Mulla, N.; Hopper, A. O.; Schechter, A. N.; Power, G.. and Gladwin M. T. 2004. Inhaled nebulized nitrite is a hypoxiasensitive NO dependent selective pulmonary vasodilator. Nat. Med., 10: 1122-1127.

[3]Shepherd, G. and Velez L. 2008. Role of hydroxocobalamin in acute cyanide poisoning. Ann Pharmacother., 42(5):661-669.
[4]Ismail, A. M.; Mostafa, A. M. and Abd El-Rahman, G. B. 2003. Microscopic studies of the effects of some food additives on thew kidney of albino rat. Egy. journ. Hosp. med.12: 12-27.

[5]Naithaniv, V.; Singhal, A. K. and Chaudhary, M. 2011. Comparative evaluation of Metal Chelating, Antioxidant and Free Radical Scavenging activity of TROIS and six products commonly used to control pain and inflammation associated with Arthritis. Intl. journ. of drug development and research 3(4):0975-9344.

[6]Zadák, Z.; Hyspler, R.; Tichá, A.; Hronek, M.; Fikrová, P.; Rathouská, J.; Hrnciariková, D. and Stetina, R. 2009. Antioxidants and vitamins in clinical conditions. Physiol Res 58(1) :13-7.

[7]Shukla, S.; Chatterji, S.; Mehta,S. ; Rai, P. K.; Singh,R.K.; Yadav, D.K. and Watal, G. 2011 . Antidiabetic effect of Raphanus sativus root juice. Jan. 49(1): 32-37.

[8]Wang, L. S.; Sun, X. D.; Cao, Y.; Wang, L.; Li, F. J. and Wang, Y. F. 2010. Antioxidant and pro-oxidant properties of acylated pelargonidin derivatives extracted from red radish (Raphanus sativus var. niger, Brassicaceae). Food Chem. Toxicol. 48(10):2712-8.

[9]Beevi, S. S.; Mangamoori, L. N.; Subathra, M. and Edula, J.R. 2010 . Hexane extract of Raphanus sativus L. roots inhibits cell proliferation and induces apoptosis in human cancer cells by modulating genes related to apoptotic pathway. Plant Foods Hum. Nutr. 65(3):200-9.

[10] Harborne, J. B. 1973. Phytochemical methods, a guide to modern technique of plant analysis. Halsted press. John Wiley and sons. New York. P. 278-281.

[11] Evans, W. C. 1997. Trease and Evans Pharmacognosy. Hartcourt 
Brace and Company. $14^{\text {th }}$ ed. Asia Pvt. Ltd., Singapore PP: 226-227.

[12] Rodkey, F. L.; Hill, T. A.; Pitts, L. L. and Robertson, R. F. 1979. Spectrophotometric measurement of carboxyhemoglobin and methemoglobin in blood. Clin Chem., 25(8): 1388-1393.

[13] Ohkawa, H.; Ohishi, N. and Yagi, K. 1979. Assay of lipid peroxides in animal tissues by TBA reaction. Anal. Biochem., 95: 351358.

[14] Beulter, E. 1975.Glutathione. In: Beulter, E. (Ed.), Red Cell Metabolism: a Manual of Biochemical Methods. Grune and Stratton, New York, PP. 105-107.

[15] Lissi, E. 1998. Autocatalytic oxidation of hemoglobin by nitrite: a possible mechanism. Free Radic. Biol. Med. 24 (9):1535-1536.

[16] Helal, E.; Zahkok, S.; Ghada, Z. A. S.; Al-Kassas, M. and Abdel Wahed, H. 2008. Biochemical Studies On The Effect Of Sodium Nitrite And/Or Glutathione Treatment On Male Rats. Egy. journ. of Hosp. med., 30: 2538.

[17] Voja, P.; Dusica, P.; Gordana, K.; Dusan, S.; Tatjana, J.S.; Snezana, C. and Dragana, V. 2007. Effect of monosodium glutamate on oxidative stress and apoptosis in rat Thymus. Mol Cell Biochem., 303:161-166.

[18] Hassan, H. A. and Yousef, M. I. 2010. Ameliorating effect on chicory (Cichorium intybus L.)supplemented diet against nitrosamine precursors-induced liver injury and oxidative stress in male rats. Food Chem. Toxicol. 48 (8-9):2163-2169.

[19] Popova, M. P. and Popov, C. S 2005: Effect of chemical agents on some enzyme activities and on the stability of membrane structures. Bulg. J. Vet. Med. 8(3): 163-171. [20] Kalaivanam, K. N.; Dharmalingam, M. and Marcus, S. R. 2006. Lipid peroxidation in type 2 diabetes mellitus Int. J. Diab. Dev. Ctries., 26 (1):30-32.

[21] El-Sheikh, N. M. and Khalil, F. A. 2011. L-Arginine and Lglutamine as immunonutrients and modulating agents for oxidative stress and toxicity induced by sodium nitrite in rats, Food and chem. Toxicology., 49: 758-762.

[22] Amin, K. A.; Abdel Hameid, H. and Abd Elsttar, A. H. 2010. Effect of food azo dyes tartrazine and carmoisine on biochemical parameters related to renal, hepatic function and oxidative stress biomarkers in young male rats. Food and Chem. Toxicology., 48: 2994-2999.

[23] El-tohamy, M. M.; El-nattat W. S. and El-kady, R. I. 2010. The Beneficial Effects of Nigella sativa, Raphanus sativus and Eruca sativa Seed Cakes to Improve Male Rabbit Fertility, Immunity and Production. journ. of Am. sci.6(10):1247- 1255.

[24] Hou, D. Y.; Hui, R. H. and Li, T. C. et al., 2011. Determination of fatty acids and octadecatrienoic acid in radish seed," journ. of Chin. Mass Spectrometry soc. 32: 108-111.

[25] Pal, R. S.; Ariharasivakumar, G.; Girhepunjhe, K. and Upadhay, A. 2009. In-vitro antioxidative activity of phenolic and flavonoids compounds extracted from seeds of Abrus precatorius. Intl. journ. of pharm. and Pharmaceutical sci. 1: 136-140. 


\title{
التاثير الواقي لبذور الفجل (Raphanus sativus) ضد الاجهاد التاكسدي

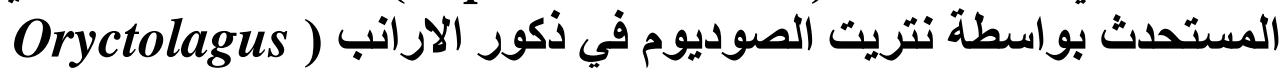 (cuniculus
}

مختار خمبس حبه

$$
\text { عالية حسين علي }
$$

لينا احمد عبد العزيز

قسم علوم الحياة / كلية العلوم للبنات / جامعة بغداد

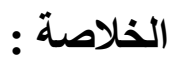

أن الهذف الرئيسي لهذه الدراسة هي معرفة التاثير الواقي لبذور نبات الفجل على الاجهاد التاكسدي المستحدث التهاث

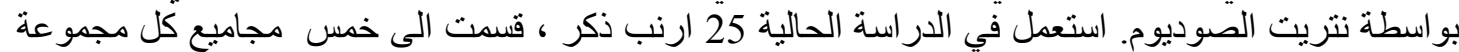

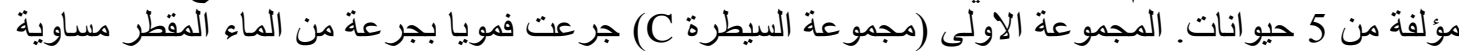

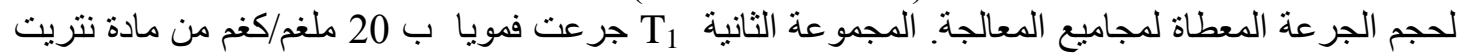

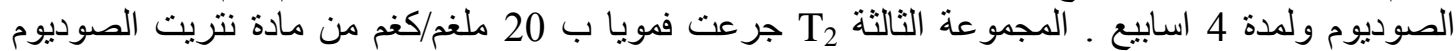

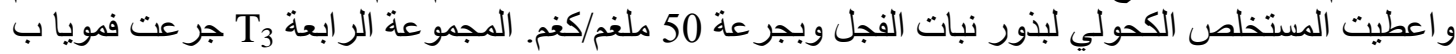

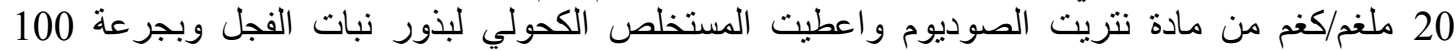

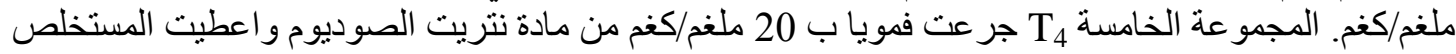

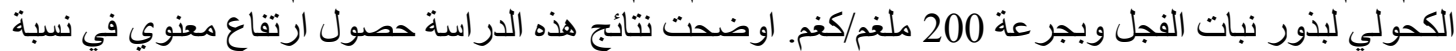

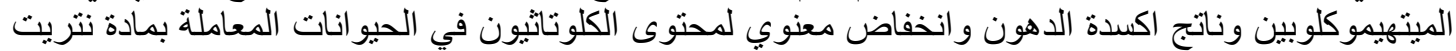

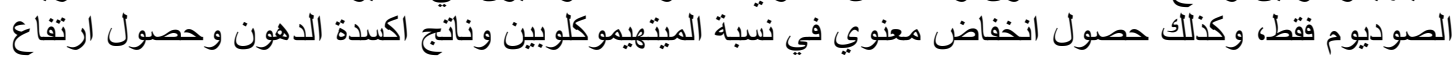

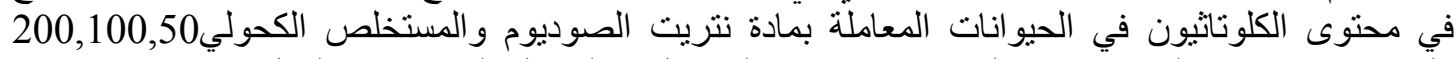

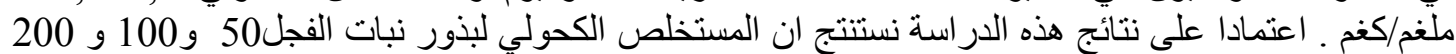

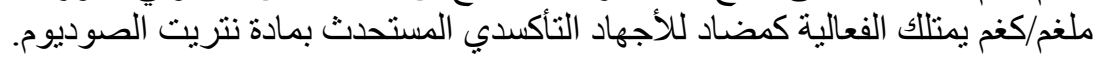

الكلمات المفتاحية : بذور نبات الفجل، نتريت الصوديوم، ميتهيمو غلوبين، ماونداي الديهايد، كلوناثايون. 